\title{
TAXATION AND REGULATION AS BARRIERS TO INTERNATIONAL INVESTMENT FLOWS \\ by
}

DEEPAK LAL

\author{
Working Papers Number 785 \\ Department of Economics \\ University of California, Los Angeles \\ Bunche 2263 \\ Los Angeles, CA 90095-1477 \\ September 1998
}


Paper for Mont Pelerin Society 1998 Golden Anniversary meeting, Washington DC, Aug.30-Sept.4th 1008, to be published in Journal Des Economistes et des Etudes Humaines.

\section{TAXATION AND REGULATION AS BARRIERS TO \\ INTERNATIONAL INVESTMENT FLOWS}

by

Deepak Lal

James S.Coleman Professor of International Development Studies, University of California, Los Angeles

and

Professor Emeritus of Political Economy, University College, London.

\section{ABSTRACT}

The paper examines the shifts in attitudes to foreign investment; charts the dimensions and composition of capital flows to develeping countries; outlines existing barriers and the effects of taxation on these flows, and critically examines the demand for their regulation in the light of the Asian crisis.

JEL classification: F3, F21, F23

Address :

Dept. of Economics, UCLA, 405 Hilgard Avenue,

Los Angeles, CA 90024

Tel : $310-825-4521$

Fax: 310-825-9528

email: dlal@ucla.edu

Revised

September 1998 
TAXATION AND REGULATION AS BARRIERS TO

INTERNATIONAL INVESTMENT FLOWS

by

Deepak Lal

INTRODUCTION

Over the last decade there has been a sea change in public attitudes to international investment around the world. The first section examines this shift in historical context. The opening up of the capital account of the balance of payments in many developing countries, the final ending of exchange controls in OECD countries (in 1979 in the UK), the progressive deregulation of domestic capital markets in most developed and increasingly in many developing countries, and the linking of global financial markets through the computer, have led to an explosion in international capital flows in the 1990's, whose dimensions and composition are charted in the second section. This growing integration could be taken as an indication that few barriers remain to the flow of international capital. The third section examines whether this is the case by surveying studies which have attempted to compare the current extent of integration with that at the end of the first liberal international economic order (LIEO) in the 19th century. This provides some indirect evidence of current barriers to international flows of capital. The fourth section looks at the effects of taxation on these flows, and the final section at the growing clamor for their regulation -or postponement of deregulation- particularly in the light of the recent Asian financial crisis. Given my expertise and to delimit the otherwise unlimited scope of the paper I will largely be dealing with developing countries. 
I. CHANGING ATTITUDES TO FOREIGN CAPITAL ${ }^{1}$

The first LIEO created under British leadership after the repeal of the Corn laws in 1846, was marked by free movement of goods, labor and capital. This led to great booms in foreign lending to the areas of new settlement in America and the Antipodes as well as many parts of the Third World. These booms were promoted by the extension of norms of conduct based on classical liberalism -in particular the sanctity of private property- through the expansion of Pax Britannica, and its influence on the local legal institutions of many independent states, as in Latin America. A strict set of legal rules was established through a number of commercial treaties between European states (see Lipson (1985)) .

But this liberal stance did not survive the advent of the First World War, which marked the beginnings of the Road to Serfdom leading to collectivist experiments around the world. These did not come to an end till the collapse of its most egregious example in 1989. With the Soviet and Mexican revolutions, the legitimacy of the 19th century rules had begun to be questioned- not least in the Third World with the explicit introduction of etatist policies by Ataturk in Turkey as a means of economic development. Subsequently, there was a worldwide erosion of public acceptance of the sanctity of private property rights when faced with social policies designed to promote the general -usually nationalist-weal.

With the establishment of Pax Americana after 1945, there was a partial restoration of these 19 th century international property rights. But this did not extend to the Third World, which experienced an explosion of economic nationalism, as following decolonization, these new nation-states were determined to assert their rights of national sovereignty against any purported international property rights. Direct foreign investors, having

'This section is based on Lal (1990) 
provided more local hostages to fortune, bore the brunt of the deleterious effects of this disintegration of the legal order. Most developing country governments (and many European ones too) being both nationalist and dirigiste, sought to regulate, tax or nationalize particular foreign investments on grounds of national social utility rather than any particular antagonism to private property. This made it difficult for the US to identify expropriation of foreign capital with a socialist ideology, as the nationalization of foreign oil companies in the 1960's and early 70's by right-wing governments in the Middle East proved. With exchange controls ubiquitous in the Third World, short term capital flows were also effectively snuffed out. Official capital flows filled the breach (see Lal (1996)).

Ironically, the tide began to turn with the OPEC coup of 1973. Besides generating the Third World demand for a planned distibutivist global economy (christened the New International Economic Order (NIEO)), it also created the massive OPEC surpluses whose recycling by offshore subsidiaries of Western commercial banks to many Third World countries- particularly in Latin America- led to the 1980's debt crisis. This in turn precipitated the process of worldwide economic liberalization. First, haltingly and then, since 1989, as a flood. This brought the age of collectivism to an end.

As the owners of the OPEC surpluses were Third World creditors, the distinction between developed country capital exporters and developing country capital importers became blurred. A process furthered in the 1980's and 1990's by the evolution of many of the successful East Asian NIC's into important foreign direct investors around the world. A growing convergence in the interests of both developed and developing countries in protecting international property rights is now evident, and international institutions like the OECD and WTO are undertaking to develop a multilateral legal regime for capital flows to parallel that for trade in goods and services. If such a regime is needed and what rules should be adopted are questions we take up later. 
The communications revolution and the ending of exchange controls led to the linking of developed country financial markets. The sheer weight of the resulting transactions across the foreign exchanges led to a steady erosion of the powers of national governments to act as the currency monopolists of yore. In effect, the denationalization of money sought by Hayek was in place. Even in developing countries, with their exchange controls, the massive capital flight that accompanied the debt crisis, particularly in Latin America, demonstrated the impotence of national authorities pursuing 'unsound' polices. It impelled them to undertake the liberalization of their economies, which is now the hallmark of a worldwide Age of Reform.

But a backlash against the political effects of this globalization- particularly as it effects the role of national governments in the economy- is already in place and poses an incipient threat to the recently resurrected LIEO. There are ongoing attempts to regulate the offshore banking centers, and various variants on the Tobin tax being proposed to throw sands in the working of international financial mechanisms to allow the old Keynesian policies- which depended on controls of short term capital- some room to work. These regulatory proposals also hope to reduce the purported volatility of short term flows- which on one view is due to the their speculative nature- and which is supposed to have brought the Asian tigers to their knees. These are also issues I take up later.

As sound fiscal policies are very much a part and parcel of the new Age of Reform, governments of every political stripe have faut de mieux been impelled to embrace the privatisations pioneered by Lady Thatcher, and to increasingly seek private financing of what were in the past considered to be the sacred cows of the public sector - the natural monopolies providing various infrastructure services. Given other competing demands for domestic savings, increasingly, foreign investment on the 19th century pattern is being sought to finance and build this infrastructure. But old habits die hard, and various forms of 
dirigiste regimes are in place or being proposed to regulate such investments in 'public goods'. We also examine the validity of these arguments for regulation in a later section.

\section{DIMENSIONS OF INTERNATIONAL CAPITAL FLOWS}

Table 1 and Fig.1, provide a summary of the size and composition of recent capital flows to developing and non-OECD countries respectively. Some notion of how these figures relate to global capital flows is provided by the following statistics: in 1995 borrowing on international capital markets was \$1.3 trillion, of which the non-OECD share was $20.4 \%$, while their share in foreign direct investment (FDI) flows was 35.2\%. (OECD (1997)).

From this data it is apparent that, official flows which were the dominant form of foreign capital flows to developing countries in the 1960's-80's are now a diminishing share, and of the private non-politicized flows the largest share (53\%) is accounted by FDI, followed by private debt (33\%) and portfolio equity flows (14\%). Razin et.al (1998) note that this pattern of private flows mimics the pecking order in corporate finance of the capital structure of firms- with internal financing (corresponding to FDI) being preferred above external finance, and debt being preferred to equity (in case where the latter is needed).

What is the contribution of FDI (the most important flow to developing countries) to world GDP and that in developing countries? Table 2 (from World Bank(1997)) provides the answer, while Fig.2, shows the relative share of FDI flows in world, developing country and OECD GDP. Both show the growing importance of FDI in world production.

In many industries there is a new international division of labor emerging in the communications age, mediated by multinational companies. This is described as "just in time production" by the World Bank (1977). In this contemporary version of an international 'putting out system' the centers in developed 
countries provide the design and marketing capacity for the production of bespoke products tailored to changing and highly differentiated tastes, which are produced 'just in time' by flexible production facilities in the cheapest production locations around the world- most often in developing countries. Fig. 3 provides some quantitative dimensions of the growing scale of this system of 'virtual factories'.

\section{ARE WORLD CAPITAL MARKETS INTEGRATED?}

But how well integrated are world capital markets, or are they still segmented by regulatory and tax barriers? Answering this question has spawned a vast literature masterfully surveyed by Obstfeld (1995) (Also see Lessard (1991)). Most of these studies examine the extent to which world capital markets correspond to the 'nirvana' model of perfect capital mobility in an Arrow-Debreu world. In this Utopia, (i) the law of one price would hold with an asset's price being the same wherever it is sold; (ii) there would be mutual insurance against purely idiosyncratic fluctuations in national consumption leading to consumption co-movements among countries being positively correlated; (iii) there would be an efficient international allocation of investment with rates of return to investment being equalized among countries.

As the real world relevance of this nirvana economics is questionable (see Lal(1998)) it is hardly surprising that these predictions are not borne out.

Nor can much be made of the stylized facts used to suggest that international capital markets are inefficient (see Lessard (1991)). These include:(1) domestic savings and investment rates are highly correlated suggesting that international capital flows have little effect in linking global savings and investment (the Feldstein-Horioka (1980) effect). (2) Asset portfolios show a marked 'home market' bias relative to the ideal (Tesar and Werner (1995)). (3) The internationalization of the market for corporate 
control is limited and asymmetric.

A better way to judge how far current global capital market integration has proceeded is by comparison with the situation at the height of the 19th century LIEO- when we know that tax and regulatory barriers were minimal. There are two ways to make this comparison: through a price or a quantity route. As we do not have historical data on identical assets in different markets comparable to the onshore-offshore Euro-currency price differentials which have been used to judge integration today, faut de mieux we have to rely on the quantity route.

The latter route (via quantity) is based on the argument that in a completely integrated global capital market, as the productivity of a country's investment is not necessarily linked to the determinants of its savings rate, a rise in the latter should lead to their most efficient deployment world wide, which ceteris paribus should lead to a current account surplus and a capital outflow, and conversely if there is a rise in the productivity of a country's investment, to a capital account deficit and a capital inflow. This has been used by Feldstein and Horioka (1980) to argue that, in such a world, the savings and investment rates in a particular country should not be systematically associated. They suggest a cross section regression of the form:

$$
(I / Y)^{j}=a+b(S / Y)^{j}+u^{j}
$$

where $\mathrm{I} / \mathrm{Y}$ is the investment ratio; $\mathrm{S} / \mathrm{Y}$ the savings ratio, and $u$ a random disturbance for each country j. If capital is completely immobile $\mathrm{b}=1$, so that the lower the value of $\mathrm{b}$ from unity the greater the degree of capital mobility.

There are various problems with the implementation and interpretation of these type of regressions. ${ }^{2}$. But, despite this, as the data on savings and investment rates is readily available, faut mieux, at least an imperfect measure of capital market integration can be derived. There are moreover, two sets of data

\footnotetext{
${ }^{2}$ See Obstfeld (1995) for details.
} 
(with somewhat different countries covered) which allow us to obtain estimates of b from the late 19th century to the present. These are those compiled by Taylor (1996) and Maddison (1991, 1992). Taylor has estimated the b coefficients for his historical data and we have done so for the Maddison data. The resulting values are charted in Figure 4. It also incorporates the estimated coefficients for a pooled sample of Taylor and Maddison countries.

A similar story emerges from all three trends in the bestimates, which is in consonance with the qualitative historical evidence we have on changing capital mobility over this long period. ${ }^{3}$ What this shows is that, till 1900 there was growing capital market integration, which was partially reversed in the early part of this century. There was a partial recovery in integration in the 1920s, but with the Great Depression and the Second World War there was further disintegration which continued into the post-war period till the 1960s. This was followed by some increased integration, but which did not become marked till the 1980s. So that now the index is roughly where it was in 1870 . Harberger (1980) has rightly argued that for judging capital market integration the evidence on rates of returns to private capital is more relevant than these savings-investment regressions. Basing himself on the estimates he made of aggregate real rates of return to capital in 18 countries in Harberger (1978) and summaries of studies of private rates of return to private capital in 6 countries, as well as estimates of gross capital flows in and out of 100 countries as a fraction of each one's gross investment, he concludes that, the evidence is in consonance with the expectation of a reasonably well-functioning world capital market. But this is not the textbook model of a perfect capital market where changes in investment are completely mediated by corresponding movements in the country's capital

${ }^{3}$ See Taylor (1996, p. 13) for details and references. For the current period see Obstfeld (1995) and Goldstein (1993). 
account. The reason for this is the asymmetric perceptions of default risk by borrowers and lenders in the world capital market, so that foreign lenders apply a risk premia to foreign lending. This would be sufficient to generate the real world capital market where domestic investment (savings) is partially financed (finances) by domestic savings (foreign investment).

In addition there are a number of policy induced set of potential barriers to the efficient functioning of international capital markets identified by Lessard (1991). These are : (1) capital controls (2) tax regime interactions which effectively impose a tax on cross- border flows (3) discrimination between domestic and foreign claimants in contract enforcement. These are the barriers we examine in the next two sections.

\section{TAXATION OF INTERNATIONAL FLOWS.}

To see the variety of disincentives and incentives to the major form of international flows - FDI- Table 3 provides UNCTAD's summary of the major policies effecting the entry and operations of foreign investors. It is impossible in this paper to examine all these in any detail, but there is a simple framework which allows us to integrate various aspects of the policy regime to judge the determinants of the social profitability of FDI from the viewpoint of the host country.

The first point to note is that, all the public interventions effecting a particular FDI can in principle be identified as equivalent to particular taxes and subsidies, which effect the income stream of the foreign investor, and the host country's national income. Using the social cost benefit framework for project evaluation developed by Little-Mirrlees $(1974)^{4}$ we can succinctly express the net social benefit (NSB) and net private benefit (NPB) from the operation of FDI in any year(t) as:

(I) $\quad \mathrm{NSB}=\mathrm{P}_{x \mathrm{xf}} \mathrm{X}-\ll \mathrm{a}_{i} \cdot \mathrm{P}_{\mathrm{if}}-\ll \mathrm{h}_{j} \cdot \mathrm{W}_{\mathrm{sj}}+\mathrm{E}+\mathrm{K}-\mathrm{d}-\mathrm{v}$

\footnotetext{
4 Also see Lal (1974), (1980)
} 


$$
\begin{aligned}
& \mathrm{NPB}=d+\mathrm{V}=\mathrm{P}_{x d} \mathrm{X}-\ll \mathrm{a}_{i} \cdot \mathrm{P}_{\mathrm{id}}-^{\ll} \mathrm{h}_{j} \cdot \mathrm{W}_{j}-\mathrm{r}-\mathrm{T} \\
& \text { i } j
\end{aligned}
$$

where the time subscripts ( $t$ ) have been suppressed and : $P_{f}$ is the border ('world') price of the output (x) and inputs (i)

Pd is the domestic price of output (x) and inputs (i)

$\mathrm{X}$ is the output

$a_{i}$ the input of i'th good including costs of plant and machinery

$h_{j}$ the input of j'th type of labor

$W_{s j}$ the 'shadow' wage for $j$ 'th type of labor

$W_{j}$ the market wage for j'th type of labor

$E$ the net external effects of the investment if any

$K$ the capital inflow inclusive of retained earnings

d the dividends and capital repatriated

$v$ the retained earnings of the foreign investor

$r$ the return to domestic capitalists if FDI is a joint venture

$\mathrm{T}$ sum of all direct taxes levied on the foreigner.

Substituting for $(d+v)$ in I from II, yields:

(III) $\quad \mathrm{NSB}=\left(P_{x f}-P_{x d}\right) X+{ }^{<<} a_{i}\left(P_{i d}-P_{i f}\right)+{ }^{<<} h_{j}\left(W_{j}-W_{s j}\right)+E+K+r+T$

The contribution of the last four terms to NSB from FDI measure its direct benefits, viz, through the direct taxes paid, the return to associated domestic capital in the case of a joint venture $^{5}$, the net capital inflow and any net external effects associated with the project. The third term represents the net implicit tax on the foreigner for using domestic labor at a wage above its social opportunity cost, whilst the first two terms take

5 This term will only contribute to the NSB from FDI compared with an identical project financed from domestic sources if the return to domestic capitalists is higher than the social discount rate in the country. For to get the NPV of the FDI, the stream of dated NSB's given by III, has to be discounted by this rate. 
account of the effects of the protective regime, with tariffs on the FDI's output providing a subsidy and on its inputs a tax. The combined effects of these two trade related measures can be shown by making use of the definition of the effective rate of protection $(E P R)^{6}$

! which yields the respective net benefits as:

(IV) $\quad \mathrm{NSB}=-\mathrm{EPR} \cdot \mathrm{V}^{\star}+{ }^{<<} \mathrm{h}_{j}\left(\mathrm{~W}_{j}-\mathrm{W}_{s j}\right)+\mathrm{E}+\mathrm{K}+\mathrm{r}+\mathrm{T}$

(V) $\quad \mathrm{NPB} \quad=(1+\mathrm{EPR}) \cdot \mathrm{V}^{*}-{ }_{j}{ }^{<} \mathrm{h}_{j} \cdot \mathrm{W}_{j}-r-\mathrm{T}$ where $V^{\star}$ is value added at world prices.

It is immediately apparent that a free trade regime maximizes the social benefits from FDI to the host country, whereas inducing import substituting, tariff-jumping FDI could harm the country as has in fact been found by numerous empirical studies. (see Lal (1975); Lall and Streeten (1977), Balasubramanyam and Sapsford (1996)). These expressions also show that all the so-called concessions or discriminatory measures for inducing or retarding different types of FDI shown in Table 3 also have no rationale. The optimal amount of FDI is induced by maintaining free trade, a level playing field in terms of infrastructure etc between domestic and foreign firms, and in charging both, the true social costs of its provision. Moreover, as a number of studies have shown ${ }^{7}$ tax and special fiscal incentives have little effect on FDI. So fiscal competition to attract FDI is not sensible. But as a study of US FDI in Mexico (Shah and Slemrod (1991)) shows it is sensitive to the tax regimes in Mexico and the US and the relative regulatory environments. So what principle should countries adopt in taxing FDI, assuming as much of this literature unrealistically does that countries are ruled by Platonic Guardians?

An extension of the argument justifying the Little-

6 The EPR defined by the ratio of value added at domestic(V) to border (world) prices (V*):

$(1+E P R)=V / V^{*}=\left(P_{x d} \cdot X-{ }^{<} a_{i} \cdot P_{i d}\right) /\left(P_{x f} \cdot X-{ }^{<} a_{i} \cdot P_{i f}\right)$

${ }^{7}$ see World Bank (1997) n.19, p.53 for references. 
Mirrlees(LM) shadow pricing rules used above (see Diamond-Mirrlees (1971)), provides the justification for basing such taxation on the 'residence principle'. This can be seen as follows. Even in an economy which has to use distortionary taxation to finance public expenditure, so that there are divergences between domestic marginal rates of substitution and transformation, to attain a 'second-best' welfare optimum, the economy should still operate with productive efficiency: given by the condition that the marginal domestic rate of transformation should equal the foreign rate of transformation under free trade. (see Lal (1974) for an explication).

This argument is applied to a simple intertemporal model of a small open economy in an integrated world economy by Frenkel, Razin and Sadka $(1991)^{8}$ depicted for the two period case by Fig. 5. OYt is the current endowment consisting of current GDP plus the inherited capital stock from the previous period. With no investment, private and public consumption in the next period will be $\mathrm{OY}^{0 t+1}$. With investment given by leftward movements from Yt, the economy can produce present and future private and public consumption given by the domestic transformation curve ABM. With perfect capital mobility, the economy will produce at $B$, where the domestic rate of transformation equals one plus the world interest rate $(1+r)$. With foreign borrowing of $I_{f}=C t z t$, the economy's intertemporal consumption frontier is $\mathrm{RC}_{2} \mathrm{Q}^{*}$. If there is no public consumption, $\mathrm{C}_{2}$ represents the intertemporal consumption equilibrium. If the desired public consumption level is Gt and $\mathrm{G}_{t+1}$ in the two periods, then the private intertemporal consumption frontier is given by $M C_{0} Q$. Assuming that the government can finance its expenditures in both periods through lump-sum taxes, the private consumption point will be at $\mathrm{C}_{1}$, with the domestic rate of substitution in consumption being equated to the domestic and foreign rates of transformation.

Suppose the government has to use distortionary taxes to

'also see Frenkel and Razin (1996). 
finance its consumption. In that case following from the second best Diamond-Mirrlees theorem it should still maintain productive efficiency by producing at $B$, but tax intertemporal domestic consumption by levying a tax on domestic residents of their incomes (including that from abroad) given by the difference in the slope of the MQ line and the slope of the indifference curve passing through Co where the price consumption curve PCC (with origin $Q^{*}$ ) cuts (or is tangential) to the private intertemporal consumption frontier MQ. The domestic and foreign marginal rates of transformation would still be the same but no longer equal to the marginal rate of substitution of intertemporal consumption at the new private consumption point Co.

By contrast if the government used the source principle of taxation, it would distort the equality between the domestic and foreign rates of transformation, as the domestic production point shifts to the right of $B$. So from the viewpoint of optimal tax theory, direct taxes in an integrated world economy should be based on the residence principle.

What, if more realistically the state is not run by Platonic Guardians, as this theory assumes, but is predatory? The relevant framework is provided by Brennan and Buchanan (1980). To limit the predatoriness of the state, they rightly recommend that, instead of the optimal tax theorem that the state should levy taxes on goods and factors of production whose demand and supply curves are relatively inelastic (which minimizes the Harberger triangle losses associated with distortionary taxation), the predatory State should be constitutionally limited to only levy taxes on goods and factors that are in relatively elastic supply. This allows 'exit' and hence limits the amount that a revenue maximizing predatory state can garner.

As it turns out, in an integrated world economy, mobile capital's supply is likely to be fairly elastic. Even if its direct taxation is based on the residence principle to ensure second best productive efficiency, as long as the state finds it difficult to tax foreign-source income because of enforcement 
difficulties, the otherwise predatory behavior which would ensue if it could effectively implement the residence principle, will be restrained- as domestic residents shift their capital from home to abroad. The net effect will be that in practice the predatory state will only be able to tax domestic source income but without introducing the distortion which would be caused to productive efficiency if it used the source principle of taxation!

This can be seen from Fig.5, where in fact the tax equilibrium shown for the residence principle is not- as is common in optimal tax theory- for some socially optimal level of government consumption, but for the predatory revenue-maximizing level: given by the tangency of the after tax private intertemporal consumption frontier $\mathrm{MQ}$ with the price consumption curve PCC. But now, without the ability to enforce taxation of foreign source income, domestic residents can escape the predatory tax rate by shifting their domestic investment abroad- on which in effect there is no effective taxation. As the prey flees, the predator will have to reduce the tax rate, hoping that at low enough rates it will not be worth domestic resident's while to evade the tax on their foreign source income.' A natural limit would have been placed on the predatory state's base instincts, whilst still maintaining productive efficiency. ${ }^{10}$

'However, as Razin and Sadka (1991) show if foreign source income cannot be taxed, then a Platonic Guardian government would institute capital controls on second best social welfare grounds. But of course, as much of optimal tax theory this is a recommendation which would be in the interests of the predator and not the prey if government's are not (as we know they are not) Platonic.

${ }^{10}$ Within the optimal tax framework Razin et al (1998) show that if there are information asymmetries which impede flows of foreign debt investment and foreign equity flows, these flows should be taxed differently from FDI for which there should be no capital income tax for non-residents. For the others, the nonresident tax rate is lower than for residents for foreign debt and negative for foreign equity flows. There are no domestic corporate taxes charged on FDI, but these are positive in the case of equity and high in the case of foreign debt flows. 
How does this principle relate to the cost-benefit formula developed above? If the residence principle is applied then no taxes should be levied on the foreign investor, for while this may increase the social return from one particular investment, by discouraging foreign investment in general, it will lower its total value below the socially optimal level. There is however one case where the host country should levy a tax on the foreign investor. This is if the foreign investor's home country grants tax credits against foreign taxes paid. In that case the home country should levy a tax on the foreign investor at the rate it would have to pay in its own country- on the residence principle- if it paid no tax in the country of its operation.

$$
\text { Given the multiplicity of tax regimes and their }
$$
complex interactions not much more can be said about the general principles for taxing foreign investment. By and large, in an increasingly integrated world capital market, taxes on capital (both domestic and foreign) will faut de mieux have to remain low. This is an outcome that classical liberals should applaud. However, there have been calls for tax harmonization of tax regimes on foreign capital, and a proposal by the OECD to attempt to regulate so called offshore tax havens- on the grounds that these are now mainly centers for money laundering, particularly by the large worldwide drug industry.

As regards the latter argument, as Krueger (1998) has rightly argued, the illegal drug industry and its massive profits are the result of inappropriate public policies towards drugs. The 'distortion'- in the parlance of the modern theory of trade and welfare- that the regulation of drugs attempts to cure is a 'domestic distortion', due to a purported negative externality in the consumption of drugs. As is well known, this requires a domestic tax (which could be infinite- implying a consumption ban) to correct the distortion. Attempting to effect supply by either imposing restrictions on domestic or foreign production (through supply measures or tariffs and quotas) will lower domestic welfare. Most of the illegal drug profits are generated by the 
restrictions and regulations imposed on suppliers. These are inefficient and also inequitable. The optimal policy would be to legalize the drug trade but to impose taxes on the consumption of drugs in the consuming countries. If this is done, there would be no danger from money laundering to undermine the offshore banking centers. They could (as they should from a classical liberal viewpoint) continue to provide that competition amongst tax jurisdictions on the Tiebout principle, which will lead to the competitive harmonization of tax systems on capital on the residence principle. (Frenkel, Razin and Sadka (1991)). There is no need for any centralized process of tax harmonization by governments.

The need for any such harmonization, and hence for international co-operation, would only arise -in principle- if the authorities could manipulate the terms of trade. This case would be identical to that of foreign trade (see Jones(1967)), where it has been well known since Mill that, a country with monopoly or monopsony power in trade could garner more of the cosmopolitan gains from trade by levying the so-called 'optimum tariff'. To prevent this outcome, as well as the possibility of a trade war between a number of countries levying their optimal tariffs, which would diminish the cosmopolitan gains from trade, international co-operation in the form of an agreement to eschew the use of such tariffs could maximize each country's as well world welfare. However, it is even less likely than for foreign trade that any country (even one as large as the US and the prospective EU) will have enough monopoly or monopsony power in world capital markets to make it worthwhile to levy the equivalent 'optimal tariffs' on capital. Therefore, competition amongst different tax jurisdictions should lead to the optimal residence principle being adopted globally for the taxation of capital. ${ }^{11}$

11 However, as Sinn (1990) has emphasized, for this ideal allocation of world capital to occur, each country needs to use the strict Schnaz-Haig-Simons definition of capital income, which excludes distortions due to accelerated depreciation, non-taxed 
V. REGULATION OF INTERNATIONAL FLOWS

Thus it seems that capital market integration is going to lead to relatively benign tax regimes for capital worldwide. Much more worrying is the growing trend towards 'harmonizing' regulatory policies. These regulations concern both FDI ( in the form of anti-trust type regulations) as well as financial capital in the form mainly of foreign bank lending. I deal with both in turn.

There are two types of regulatory problems emerging for FDI. The first is the desire to extend US style anti-trust legislation worldwide- to counteract the so-called 'monopolistic' power of global corporations. The second, of particular relevance to developing countries- whose cash-strapped public sectors are forcing them to rely increasingly on FDI to finance and produce the infrastructure which has elements of natural monopoly- is to create regulatory regimes for privatized infrastructure services. On these issues I can be brief, as I have dealt with them in some detail recently (Lal (1998a). The following points need to be borne in mind. First the intellectual basis for the regulatory regimes being proposed or for their extension ( as in the case of anti-trust) is based on the wholly inadequate and Utopian model of 'market failure' derived from the 'nirvana economics' of the Arrow-Debreu model. From the more appropriate classical notion of competition, revived most comprehensively by the UCLA industrial organization school (see Demsetz (1988, 1989)), there is no case for anti-trust legislation either nationally or internationally.

capital gains and other divergences from correct accounting. As Sinn also notes, with reference to the emerging tax harmonization in the $\mathrm{EU}$, the emerging tax regime in an integrated economy will imply that only immobile factors of production will ultimately be taxable. He laments the limit this will place on the redistributive abilities of European governments- particularly on financing their welfare states. But for classical liberals, who have always opposed the predatory state's corruption of the polity by using other people's money to demonstrate its 'compassion, this is an outcome to be devoutly wished. 
For the natural monopoly elements in infrastructure services, the appropriate policy is to organize auctions for 'competition for the field' for their provision (on the lines set out in Demsetz (1989) Chp.6). Again no regulatory regime is requires.

While the economics seems clear-cut, the attempt to roll back existing and prevent future regulations is hampered by the political economy of predatory democratic states, as witness the signal failure of the Republican Congressional majority in its attempts to do so in the US. To deal adequately with this issue would take me too far afield. But I have recently come to the view that many of these problems are due to the growing moral incoherence of the West. (Lal (1998b, 1998c). However, there may hopefully be an antidote. In particular, the US's attempts to legislate its changing and fractured morality (public and private) world wide (eg. the Helms-Burton bill and other claims to extra territorial rights to impose sanctions in line with its moral preferences) is now increasingly meeting resistance from the Rest. Though there is still the danger that this might trigger that 'clash of civilizations' hypothesized by Huntington, I am more hopeful that (as is happening in the talks on Helms-Burton between the US and the EU) an international 'disarmament' agreement will be reached where countries will forbear from imposing their ethics on others. If this happens, we will have international competition amongst national regulatory regimes (with no extraterritorial reach). As in the case of competition between tax jurisdictions, this global competition amongst national regulatory regimes should be viewed with a benign eye by classical liberals. As in most forms of competition, the converse of Gresham's law should apply with the bad being displaced by the good, i.e minimal or no regulation. What must be resisted are the various moves by international agencies to create a centralized international regulatory regime.

This brings us to the regulation of financial flows. There are two issues. The first concerns the need to regulate financial and banking institutions both nationally and internationally. Here 
the mainstream justification is again based on 'market failure'. ( See eg. King (1990)). First, on the purported asymmetries of information between buyers and sellers of financial services which it is claimed create the need for investor protection. Second, the externalities which are supposed to arise when the distress of financial institutions is supposed to lead to 'systemic' problems.

Neither argument is cogent. There is no reason why the asymmetries in information should be anymore severe in financial as opposed to many other markets providing goods and services: eg. for household goods and repairs, car maintenance, and those for second hand consumer durables. If there is no need for these markets to be publicly regulated why should there be for financial services? As regards the externality argument, it is clear that what is at issue are pecuniary externalities, which since Buchanan and Stubblebine (1962) we know are not 'Pareto relevant'. ${ }^{12}$ The same argument based on pecuniary externalities would apply to the failure of a large number of industrial companies in a country. But we do not seek to eliminate industrial bankruptcies on the grounds of systemic dangers, so why should we do so for financial institutions?

The special problems relating to financial institutions arise (as is well known) because of the moral hazard created by implicit or explicit public insurance of their deposits.This, and the fact that their business is to deal with 'paper promises', makes them prone to fraud. Which in turn leads to the perhaps justifiable demand that, as it seems politically impossible to dispense with deposit insurance, regulation is needed to create transparency in the reporting of their balance sheets as well as for the enforcement of capital adequacy criteria on these financial institutions. I discuss this aspect of the 'moral hazard' associated with bank lending in the context of

12 A number of other arguments for international co-operation based on pecuniary externalities are critically examined in my 1990 Wincott lecture (Lal (1990)). 
international capital markets below.

Before that we also need to take account of another view, which sees financial markets as being inherently unstable and requiring regulation to create greater 'economic security'. (see Minsky (1977), Kindleberger (!978)). The global equity and financial market has been described as a giant casino which needs to be controlled in the interests of the non-gambling majority of the world's citizens. (see Strange (1986)). Speculative bubbles in which over-lending is followed by collapse and crisis are purported to be endemic in capitalist economies which then require a lender of last resort to mitigate the deflationary impact of a financial crash caused by the panic following the mania which caused the bubble. ${ }^{13}$ As Flemming (1982) rightly notes about this argument, it assumes that "enterprises adopt excessively exposed geared, levered positions in a period of stability that does not in fact reflect a favorable shift in the economy's stochastic environment.. [It] depends on agents failing to distinguish a run of good luck from a favorable structural shift in their environment. Such errors are not only identifiable but also optimal if agents attach the correct non-zero probability to structural changes. If Minsky believes that people are too willing to believe that such changes have occurred, he should consider suggesting to the authorities that they intervene randomly in financial markets- by increasing their variance, such intervention would hinder the recognition of genuine shifts and should also inhibit false inferences" (p.40).

13 In this context it should be noted that there is also a large academic literature on floating exchange rates which claims that an international regime based on them is prone to speculative bubbles which lead to sustained divergences of exchange rates from their economic 'fundamentals'. The best critique and discussion of this literature on rational speculative bubbles is Mussa (1990). As he concludes: "A rational speculative bubble implies not only that people are sometimes crazy, but that they are systematically, calculatingly, and fanatically insane... I conclude therefore that rational speculative bubbles are empirically irrelevant and theoretically absurd" (PP.13-14) 
The recent turmoil in East Asia, the earlier Mexican crisis, and the 80's debt crisis, have led many observers to suggest that developing countries -with fragile domestic financial sectors and incomplete transitions from the plan to the market- should maintain some form of capital controls on short term capital inflows. The Chilean's imposition of an implicit tax on these inflows is much commended. While international dirigistes are recommending the institution of the Tobin tax on all international non-FDI flows to throw some sand into the workings of the system. The proceeds of the tax being handed over to the UNDP (See UNDP)!

While there is no merit in the latter proposal, there are problems with foreign bank lending which, the recent experience of developing countries suggests, do merit consideration. There are two problems. ${ }^{14}$ First, unlike foreign equity investment and FDI, foreign bank loans denominated in foreign currency do not involve the sharing of the foreign exchange and income risks associated with the lending by both borrowers and lenders. Second, the operations of the International Monetary Fund (IMF) have created

14 In addition to the two problems mentioned in the text there were two other factors responsible for the Asian financial crisis. The first was the quasi fixed exchange rate regime in many countries. It is increasingly becoming clear that only two exchange rate regimes are viable in a globalized capital market: a freely floating rate or a rigidly fixed one as in a currency board. These are the only ones which allow automatic adjustment to external and internal shocks without any need for discretionary action by the authorities who do not have the time or the information to deal with the actions of a highly decentralized but integrated global capital market mediating these shocks. Their actions are often inappropriate leading to serious misalignments of the real exchange rate. Second, the crisis showed up a systematic fault in the 'Asian' model of development in which there was a close linkage between the domestic banking system, large industrial enterprises and the government. By making the banking system the creature of the government's will, it creates tremendous moral hazard in the domestic banking system. When this moral hazard is combined with that created by the IMF for foreign bank lending, the economy is in double jeopardy. Foreign banks lending to domestic banks which know they will be bailed out, will over-end, leading to ropy investments and an eventual debt crisis for the country. 
serious problems of moral hazard in this part of the international capital market. The first problem implies that, when for some reason, there is a need for adjustment in the country which requires an exchange rate depreciation, the debt burden of the country denominated in local currency rises, the larger is the share of foreign bank loans denominated in foreign currency in its total debt exposure. This in itself would not matter, if the loans were contracted by private domestic agents and there was no implicit or explicit government guarantee. However, the actions of the IMF -the second problem- which has in effect become the international debt collector for foreign banks, belies the last assumption .

The recent crisis in Indonesia brings out the problem most starkly. Before the crisis, there was little wrong with Indonesia's economic fundamentals. It had also been, by LDC standards, an exceptionally well-managed economy, which despite the prevalence of 'crony capitalism' had seen one of the most impressive economic transformations in Asia - combining growth with equity- under Suharto's rule. (see Lal and Myint (1996)). Moreover, its foreign bank debt, apart from not being excessive, was also all private. When a run developed on these loans, following the panic introduced by the Thai crisis, and the rupiah had to be devalued, most of these private loans turned sour. In a well-functioning system the private borrowers would have defaulted on these loans, unless their bankers were willing to see this as a short run crisis and roll them over. But then, enter the IMF. Following on its past record in the 1980's debt and 1990's Mexican crisis, the IMF, with the backing of the US and Japan (whose banks were the most exposed and stood to lose the most), declared that there was a systemic threat to the world financial system from an Indonesian private sector default. The Indonesian government, under the smoke screen of an IMF program, was forced to take on the private sector's liabilities and promise to pay off the foreign bankers through taxes on all its citizens. This has created a serious problem of moral hazard for this type of 
lending. The smartest thing for any one to do today is to set up a foreign bank, make loans to the ropiest LDC firms at exorbitant interest rates, and when these turn sour say there is a danger to the world financial system, which the IMF will then seek to prevent by forcing the government to take over these debts and pay them back from taxing its citizens!

The ideal solution is of course to shut down the IMF. ${ }^{15}$ Since Nixon closed the Gold window it has been like Pirandello's play "Six characters in search of an author"- in search of a play. Ever since its justification as the overseer of the gold exchange standard created at Bretton Woods collapsed, with the move to generalized floating, it has had no justification. It has smartly stepped into the opportunities offered by the 80's debt crisis and the problems created by the post 1989 East European countries moving from the Plan to the market. Whatever its achievements in these respects in the past, the recent East Asian crisis now shows it to be as much part of the problem as the solution.

Suppose, however, that it is not shut down, as there is no redundant international institution- from the ILO, UNESCO, UNIDO to UNCTAD- which has died. In that case, developing countries will have to live with the continuing moral hazard in the market for foreign bank loans. How should they deal with this? Many dirigiste governments are using this as an excuse to delay or prevent any

15 In its most recent play the supporters of the IMF want to convert it into an international lender of last resort. But this is totally misconceived. There are two functions that a lender of last resort has to perform as set out in Bagheot's rule. First, it should be able to create high powered money quickly to on-lend to solvent banks to prevent a liquidity crisis. Second, it must be able to distinguish between good and bad 'paper' and thus judge the soundness of the banks to which it is extending liquidity, with the insolvent banks being liquidated. The IMF is incapable of doing either. It can only lend after lengthy negotiations with a country's government and with the approval of the board. Second it has no way of sorting out the 'good' from 'bad' loans for instance made by foreign banks to residents in the country, and to liquidate the latter. The lender of last resort function for the money center banks involved in foreign lending must therefore continue to be provided by their parent central banks. 
opening of their capital accounts. Others are thinking of adopting variants of the chilean scheme. The ideal way to deal with volatile foreign bank lending is for local central banks to ensure that all such borrowing is suitably hedged. But if they lack the requisite capital markets for such hedging, instead of the dirigiste options being offered, there is an alternative and superior market- mediated way of 'regulating' these flows. This is to recognize that the main 'systemic' danger to the country lies in the fact that these foreign bank lenders do not share in the foreign exchange risk associated with these loans. A simple way of making them do so, and thus putting these loans on a par with foreign equity and FDI, would be to allow domestic residents to borrow only in local currency. Besides raising the costs of such borrowing- implying an implicit tax on such borrowing- by imposing a capital loss on banks which run in a panic leading to a depreciation of the currency, this enforced sharing of the foreign currency risk should also give them some cause to pause. Apart from this limited and hopefully temporary 'second best' regulation - till domestic markets to hedge foreign currency exposure are well developed-there seems to be little justification for the regulation of international flows of capital. 
REFERENCES

V.N.Balasubramanyam, M.Salisu and D.Sapsford (1996): "Foreign direct investment and growth in EP and IS countries", Economic Journal, vol.106, January

M.Blomstrom and R.E.Lipsey (1989): "US multinationals in latin american service industries", World Development, vol.17, no.11.

G.Brennan and J.M.Buchanan (1980): The power to tax, Cambridge Univ. press, Cambridge.

J.M.Buchanan and C.Stubblebine (1962): "Externality", Economica, vo1.29.

R.E.Caves(1996): Multinational enterprise and economic analysis, Cambridge univ. press, Cambridge.

H.Demsetz (1988, 1989): The Orqanisation of Economic Activity, 2 vols., Blackwell, Oxford.

P.A.Diamond and J.A.Mirrlees (1971): "Optimal taxation and public production- Parts I and II", American Economic Review, March and April.

M.P.Dooley (1988): "Capital flight, a response to differences in financial risks", IMF Staff Papers, vol.35, no.3.

W.J.Ethier (1986): "The multinational firm", Quarterly Journal of Economics, vol.CI, no.4.

M.Feldstein and C.Horioka (1980): "Domestic savings and international capital flows",Economic Journal, vol.90, June.

J.S.Flemming (1982): "Comment on Minsky" in Kindleberger and Laffarge (1982).

J.Frenkel and A.Razin (1996): Fiscal Policies and Growth in the World Economy, MIT, Cambridge Mass.

J.A.Frenkel, A.Razin and E.Sadka (1991): International taxation in 
an inteqrated world economy, MIT, Cambridge Mass.

M.Goldstein, et.al.(193); International Capital Markets, IMF, Washington D.C.

A.C.Harberger (1980): "Vignettes on the world capital market" American Economic Review, vol.70, no.2.

F.A.Hayek (1978): Denationalisation of Money, 2nd edtn, Hobart paper no.70, IEA, London.

R.W.Jones (1967): "International capital movements and the theory of tariffs and trade", Quarterly Journal of Economics, vol.81, Feb.

C.P.Kindleberger (1978): Manias, Panics and Crashes, Basic Books, New York.

C.P.Kindleberger and J.P.Laffargue (eds) (1982): Financial CrisesTheory, History and Policy, Cambridge Univ. Press, Cambridge.

M.King (1990): "International harmonization of the regulation of capital markets", European Economic Review, vol.34, nos.2/3.

A.O.Krueger (1998): "International trade in Bads" in H.Giersch (ed) : Merits and limits of Markets, Springer-Verlag, Berlin.

D.Lal (1974): Methods of Project Analysis-A Review, Johns Hopkins, Baltimore.

D.Lal (1975):Appraising Foreign Investment in Developing Countries, Heinemann Educational Books, London.

D.Lal (1980): Prices for Planning, Heinemann Educational Books, London.

D.Lal (1990): "International Capital Flows and Economic Development" in scott and Lal (ed) : Public Policy and Economic Development, Clarendon Press, Oxford. Reprinted in Lal (1993).

D.Lal (1990a): "The Limits of International Co-operation", IEA Occassional paper 83, reprinted in Lal (1994).

D.Lal (1993): The Repressed Economy, Economists of the 20th century, Edward Elgar, Aldershot.

D.Lal (1994): Against Dirigisme, ICS Press, San Francisco.

D.Lal (1996): "Foreign Aid: An Idea whose time has gone", Economic Affairs, Autumn 1996.

D.Lal (1998a): "From planning to regulation-toward a new 
dirigisme?" "Cato Journal, vol.17, no.2

D.Lal (1998b): "Social standards and social dumping", in H.Giersch (Ed) : Merits and Limits of Markets, Springer-Verlag, Berlin.

D.Lal (1998c): Unintended Consequences- the impact of factor endowments, culture and politics on long run economic performance, MIT, Cambridge Mass.

D.Lal and H.Myint (1996): The Political Economy of Poverty, Equity and Growth- A comparative study, Clarendon Press, Oxford.

S.Lall and P.Streeten (1977): Foreign Investment, Transnationals and Developing Countries, Macmillan, London.

D.R.Lessard (1991): "The international efficiency of world capital markets", in H.Siebert (ed): Capital Flows in the world economy, J.C.B.Mohr, Tubingen.

D.R.Lessard and J.Williamson (ed): Capital Flight and Third World Debt, Institute of International Economics, Washington DC

D.Lim (1983): "Fiscal incentives and direct foreign investment in less developed countries", Journal of Development studies, vo1.19.no.2

D.Lipson (1985): Standing Guard-protecting foreign capital in the 19 th and 20 th centuries, Univ. of California Press, Berkeley.

I.M.D.Little and J.Mirrlees (1974): Project Appraisal and Planninq for Developing Countries, Heinemann Educational Books, London.

R.E.B.Lucas (1993): "On the determinants of direct foreign investment: evidence from east and south east Asia", World Development, vol.21, no.3.

A.Maddison (1991): "Postwar growth and slowdown: a global view", in G.Ghlen, H.Hesse and H.G.Ramser (eds) : Wachstumstheorie Und Wachstumpolitik, J.C.B.Mohr, Tubingen.

A.Maddison (1992) : "A long run perspective on savings", Scandinavian Journal of Economics, vol.94, no.2.

H.P.Minsky (1977) : "A theory of systematic fragility" in E.I.Altman and A.W.Sametz (eds) : Financial Crisis: Institutions and markets in a fragile environment, Wiley, New York.

M.Mussa (1990) : Exchange rates in theory and in reality", Princeton Essays in International finance, no.179, Princeton N.J.

M.Obstfeld (1995): "International Capital Mobility in the 1990's" 
in P.B.Kenen (ed): Understanding Interdependence, Princeton Univ. press, Princeton N.J.

OECD (1997) : The World in 2020, OECD, Paris.

A.Razin and E.Sadka (1991): "Efficient investment incentives in the presence of capital flight", Journal of International Economics, vol.31, nos $1 / 2$.

A.Razin, E.Sadka and Chi-wa-Yuen (1998): "A pecking order of capital inflows and international tax principles", Journal of International Economics, vo1.44, no.1.

A.Shah and J.Slemrod (1991): "Do taxes matter for foreign direct investment?", World Bank Economic Review, vol.5, no.3.

H.W.Sinn (1990): "Tax harmonization or tax competition in Europe", European Economic Review, vol.34 nos2/3

S.Strange (1986): Casino Capitalism , Blackwells, Oxford.

A.M.Taylor (1996): "international capital mobility in history-the savings-investment relationship" ,NBER Working paper, no.5743, sept.

L.L.Tessar and I.M.Werner (1995): "US equity investment in emerging stock markets", World Bank Economic Review, vo1.9, January •

J.Tobin (1978): "A proposal for international monetary reform", The Eastern Economic Journal, vol.4.

J.Tobin (1992): "Tax the speculators", Financial Times, 22 Dec.

World Bank (1997): Global Economic Prospects and the Developinq Countries, World Bank, Washington D.C.

United Nations (1996): World Investment Report 1996, UNCTAD, United Nations, New York.

United Nations (1994) : Human Development Report 1994, UNDP, United Nations, New York. 